\title{
AGROECOLOGIC TRANSITION IN RURAL PROPERTIES FROM THE SOUTH COAST FROM JOÃO PESSOA CITY, NORTHEAST BRAZIL
}

\author{
Deinne Airles da SILVA ${ }^{\mathbf{1}}$; Gil Dutra FURTADO ${ }^{2}$; Gabrielle Diniz dos SANTOS ${ }^{\mathbf{3}}$
}

\begin{abstract}
${ }^{1}$ Agricultural Technician/Universidade Federal da Paraíba (UFPB), Brazil; Biologist/Universidade Estadual da Paraíba (UEPB), Brazil; Specialist in Agroecology/UEPB, Brazil; Master in Development and Environment/PRODEMA, UFPB, Brazil. E-mail: deinne_airles@hotmail.com

${ }^{2}$ Graduating in Veterinary Medicine/Centro Universitário Maurício de Nassau (UNINASSAU/PB), Brazil; PostDoctoral in Development and Environment/PRODEMA, UFPB, Brazil; Doctor in Psychobiology/Universidade Federal do Rio Grande do Norte (UFRN), Brazil; Agronomist-Partner of 'Cooperativa de Serviços Técnicos do Agronegócio' (COOPAGRO), Brazil. E-mail: gdfurtado@hotmail.com

${ }^{3}$ Bachelor in Ecology/UFPB, Brazil; Specialist in Urban Planning and Cities Management/Centro Universitário de João Pessoa (UNIPÊ), Brazil; Master in Development and Environment/PRODEMA, UFPB, Brazil. E-mail: gabrielledsantos90@gmail.com
\end{abstract}

\begin{abstract}
Nowadays, the world's agriculture and livestock is undergoing transformations, where the population's appeal for an agricultural activity based on a more ecological basis is increasing giving a better quality of life to all involved, a technique that can be defined as a science, with a multidisciplinary character that has concepts, principles and methodologies, which serves to analyze and evaluate agroecosystems. Thus, in order to focus on the field reality of the rural area of the city of João Pessoa, Paraíba, located in the southern coastal area, a research was developed between properties that use the two systems of agriculture, using for that purpose the bibliographic review, qualitative research and participant observation. In the end of this work, it was observed that family traditions and the rapid return of investments in the field with the conventional agriculture and livestock hindered the implementation of a more agro-ecosystem activity which leads the extension agents to extend their work and extension techniques.
\end{abstract}

Keywords: Agropecuary; Conventional; Agroecosystem.

\section{TRANSIÇÃO AGROECOLÓGICA EM PROPRIEDADES RURAIS DO LITORAL SUL DO MUNICÍPIO DE JOÃO PESSOA, NORDESTE DO BRASIL}

Resumo. Atualmente a agricultura e pecuária mundial está passando por transformações, onde é cada vez mais crescente o apelo da população por uma atividade agropecuária de base mais ecológica, que dê mais qualidade de vida a todos os envolvidos, técnica esta que pode ser definida como uma ciência, de caráter multidisciplinar que possui conceitos, princípios e metodologias, que servem para analisar e avaliar os agroecossistemas. Assim, visando focar a realidade de campo da zona rural do município de João Pessoa, Paraíba, localizada em área litorânea sul, desenvolveu-se uma pesquisa entre 
propriedades que empregam os dois sistemas de agricultura, utilizando-se para tal objetivo a revisão bibliográfica, pesquisa qualitativa e observação participante. Na finalização deste trabalho observou-se que as tradições familiares e o retorno rápido dos investimentos no campo com a agropecuária convencional dificultaram a implantação de uma atividade mais voltada para o agroecossistema o que leva os extensionistas a ampliarem suas técnicas de trabalho e extensão.

Palavras-chave: Agropecuária; Convencional; Agroecossistema.

\section{TRANSICIÓN AGROECOLÓGICA EN PROPIEDADES RURALES DEL LITORAL SUL DEL MUNICIPIO DE JOÃO PESSOA/PB}

Resumén. Actualmente la agricultura y la ganadería mundial están pasando por transformaciónes, dónde es cada vez más creciente el atractivo de la población por una actividad agropecuaria de base más ecológica, que dé más calidad de vida a todos los involucrados, técnica que puede definirse como una ciencia, de carácter multidisciplinario que tiene conceptos, principios y metodologías, que sirven para analizar y evaluar los agroecosistemas. Así, para enfocar la realidad de campo de la zona rural del municipio de João Pessoa, Paraíba, ubicada en área costera sur, se desarrolló una investigación entre propiedades que emplean los dos sistemas de agricultura, utilizando para tal objetivo la revisión bibliográfica, investigación cualitativa y observación participante. En la finalización de este trabajo se observó que las tradiciones familiares y el retorno rápido de las inversiones en el campo con la agropecuaria convencional dificultaron la implantación de una actividad más volcada para el agroecosistema, lo que lleva a los extensionistas a ampliar sus técnicas de trabajo y extensión.

Palabras clave: Agropecuaria; Convencional; Agroecosistema.

\section{INTRODUCTION}

Nowadays, the world's agriculture and livestock farming are undergoing transformations, where the population's appeal for an ecological base farming is increasing, and giving life quality to all. This type of professional activity in the rural area is opposite of the conventional model, which is practiced on a large scale in all regions of the Earth. The agricultural sector that is practiced today in the world is a kind of agricultural activities where the search for broad productivity prevails through the intense application of external chemical inputs, making possible in the short term, economic results such as increased productivity and agricultural and livestock efficiency in a very visible way (CÓRDULA et al., 2018; DIAS, 2006).

Both landowners and family farmers, who account for large, medium and small farms, make full use of these techniques in their crops and livestock farming, which work with 
cassava, soybean, coffee, corn, sugarcane , in addition to others and the production of milk, meat, eggs, etc., from rural areas (CÓRDULA et al., 2019; SILVA; FURTADO, 2013).

This type of agriculture has strong characteristics, such as intensive capital use, largescale use of technology, does not prioritize the environment's preservation, rather uses largescale monoculture continuously, eliminates cultural remains with the application of fire, prioritizes the standardization of crop and livestock systems, exacerbates agrochemicals; produces a large quantity of products in a short period of time, considers rural property as a company only to the purpose of generating more capital and financial profits, among other characteristics (SILVA; FURTADO, 2013).

In other hand, agroecology is defined as a multidisciplinary science that has concepts, principles, methodologies, which serve to analyze and evaluate agroecosystems, going beyond technological aspects, giving importance to issues involving economic, social, environmental, political, cultural, ethical, and sustainable situations (ALTIEIRI, 2002; 2004).

The Agroecology has the concept in the development of a sustainable agricultural science and techniques, which contrasts strongly with conventional agriculture, since it employs ecologically based methods and techniques such as natural agrochemicals, multiple crops, minimum use of capital, application of technological inputs adapted to agroecology, prioritize the vegetal cover in the soil, apply organic compounds, and respect the biotics and abiotics that are interconnected, seeing the rural property within a living system, thus denominates the property by 'agroecosystem'(SILVA; FURTADO, 2013).

Faced to this exposed reality regarding the conventional agriculture and the agroecology, this article aims to focus on the rural reality of the rural zone of the city of João Pessoa, Paraíba, located in a coastal area, which has rural properties that employ both systems of agriculture.

Among the existing properties in the rural coastal region of João Pessoa, Paraíba, some have presented resistance to the agro ecological transition presented to them by the "Diretoria da Agricultura Familiar (DAF)", that is a department which takes care of family farming and prioritizes the encouraging sustainable agricultural activities .

Some properties have preferred to continue with conventional farming activities, employing techniques and methods that tend to degrade biodiversity and the natural environment, but they allow returns, such as large agricultural production and higher profits in the medium and short term (SILVA; FURTADO, 2013). The objective of this study was to show the resistance of family farms from coastal rural properties in the south of Paraíba to 
adhere to the agro ecological transition, in order to develop better tools for the awareness of agriculturalists and extensionists.

\section{MATERIALS AND METHODS}

Specific methodologies were used, such as the bibliographical review, where he excelled by the search for articles, books and specific scientific documents on the topic addressed; qualitative research, where descriptive data were obtained through direct and interactive contacts between the researcher and the object of study, and participant observation, that the act of knowing how to listen, see and make good use of all the senses together with knowing when to ask or not to ask, besides asking the questions at the appropriate time (GIL, 2002; RAUPP; BEUREN, 2006; VALLADARES, 2007).

It was followed by a chronological sequence in which a visit was made to the "Diretoria da Agricultura Familiar", where became familiar with the activities already implemented in the region of study and to strengthen contacts with the employees. In a second moment, following the planning developed; the participation took place in a training on agroecological costs, there were agriculturalists from both Agroecology as well as the conventional one.

It was used the field diary, which included valuable information from the extensionist interviews record, such as observations on informal conversations, details and expressions that made up the research theme. It included behaviors, habits, customs, among other important data (CARDOSO; FERRARI, 2006; GIL, 2002).

\section{RESULTS AND DISCUSSION}

After following the chronological sequence proposed for the research, it was observed that both in the conversation with the extensionists and in the training done with the agriculturalists, there was a resistance on the part of the field men to adopt the ecological techniques, presenting a considerable cultural resistance. The agriculturalists present this resistance, avoiding the adhesion of $100 \%$ of their activities to the agroecosystem, among other considerations, due to cultural issues, where the teachings and techniques that were passed on to them by their ancestors present a strong influence on their professional actions and decisions (SILVA; FURTADO, 2013).

For these workers, 'resisting' is the way communities have to retain their cultures in order to defend their traditions, which are distinctive traits that mark them, and imply, 
therefore, the ability to articulate varied methodologies in order to maintain a specific and own internal history, thus existing in historical time and subjective time (SANTOS, 2008).

It adds to this the fact that conventional farming provides results in a shorter time, mainly due to the use of agrochemicals and other industrialized agricultural inputs, which interferes positively in the protection of crops and livestock farming, against the presence of pests and other diseases, making agricultural activities more resilient, greatly reducing the loss of agricultural and livestock products.

\section{FINAL CONSIDERATIONS}

Farmers on the agricultural coast of the city of João Pessoa, Paraíba, like many other rural workers in all over the Northeast, have a strong custom of considering the techniques and methods of conventional farming, which have been transmitted to them by previous family generations, and passed on for decades from generation to generation.

The mission of extension workers to incorporate the new concepts on agroecosystem in the agricultural activities of these workers demonstrates a real challenge that includes expanding their work and extension techniques to demonstrate that sustainable agriculture can bring extended benefits to all, being these from social, economic, cultural and environmental nature.

\section{REFERENCES}

ALTIERI, M.A. Biotecnologia Agrícola: mitos, riscos ambientais e alternativas. Porto Alegre: ASCAR-EMATER/RS, 2002.

ALTIERI, M.A. Biotecnologia Agrícola: mitos, riscos ambientais e alternativas. Petrópolis: Vozes, 2004.

CARDOSO, I.M.; FERRARI, E.A. Construindo o conhecimento agroecológico: trajetória de interação entre ONG, universidade e organizações de agricultores. Agriculturas, v. 13, p. 28$32,2006$.

CÓRDULA, E.B.L.; NASCIMENTO, G.C.C.; FURTADO, G.D.; ABÍLIO, F.J.P. Etnografia dos agricultores de um assentamento agrícola, no município de Lucena, estado da Paraíba. Revista Educação Ambiental em Ação, n. 66, ano, XVII, 2018. 
CÓRDULA, E.B.L.; NASCIMENTO, G.C.C.; FURTADO, G.D.; ABÍLIO; F.J.P. A relação do ser humano com a natureza, em um assentamento agrícola no município de Lucena, Paraíba. Revista Educação Ambiental em Ação, n. 67, ano, XVII, 2019.

DIAS, T.F. Agricultura Convencional e Agricultura Ecológica: um debate sobre a sustentabilidade de um novo sistema agrícola. III Simpósio de Excelência em Gestão e Tecnologia, Resende, III SEGeT, 2006.

GIL, A.C. Como elaborar projetos de pesquisa. ed. 4, São Paulo, Atlas, 2002.

RAUPP, F.M.; BEUREN, I.M. Metodologia da pesquisa aplicável às ciências sociais. In. BEUREN, I.M. (Org.). Como elaborar trabalhos monográficos em contabilidade: teoria e prática. ed. 3, São Paulo: Atlas, cap. 3, p.76-97, 2006.

SANTOS, A.S. Resistências culturais como estratégias de defesa da identidade. Salvador, IV ENECULT, 2008.

SILVA, D.A.; FURTADO, G.D.A resistência dos agricultores em aderir a transição agroecológica em propriedades rurais assistidas pela DAF em João Pessoa/PB. ANAIS do X - ENFOC. Curitiba, PA, 2013.

VALLADARES, L. Os dez mandamentos da observação participante. Revista brasileira de Ciências Sociais, v. 22, n. 63, p. 153-155, 2007. 